\title{
PEMETAAN PARTISIPATIF BATAS KELURAHAN DI KECAMATAN SUKOLILO KOTA SURABAYA
}

\author{
Yanto Budisusanto, Khomsin, Renita Purwanti, Aninda Nurry M.F, Ria Widiastuty \\ Jurusan Teknik Geomatika FTSP-ITS, Kampus ITS Sukolilo, Surabaya, 60111 \\ Email : yanto_budisusanto@geodesy.its.ac.id
}

\begin{abstract}
Abstrak
Peta adalah gambaran permukaan bumi pada bidang datar dengan skala dan sistem proyeksi tertentu. Peta bisa disajikan dalam berbagai cara yang berbeda, mulai dari peta konvensional yang tercetak hingga peta digital yang tampil di layar komputer.Kegiatan pemetaan merupakan solusi yang nyata untuk menyediakan informasi spasial yang akurat dan terpercaya dalam jumlah yang cukup mengenai suatu daerah tertentu. Selain itu, kegiatan tersebut dapat menjadi sarana pemutakhiran informasi spasial yang sudah ada sebelumnya. Dengan demikian diharapkan dapat memberikan manfaat secara maksimal untuk berbagai kepentingan.Undang-Undang Informasi Geospasial (UU IG) No.4 Tahun 2011 mengatur tentang infomasi geospasial dasar dan tematik (IGD dan IGT) wilayah Republik Indonesia. Implementasi UU IG ini tidak hanya tanggung jawab dari Badan Informasi Geospasial saja akan tetapi juga merupakan tanggung jawab dari semua pemangku kepentingan yang terdiri dari pihak pemerintah, pengusaha, akademisi (perguruan tinggi) dan masyarakat. Terkait dengan UU IG ini, Perguruan Tinggi mempunyai kewajiban melaksanakan pendidikan yaitu untuk menyiapkan sumber daya manusia yang siap untuk menyelenggarakan IGD dan IGT. Selain itu, perguruan tinggi juga mempunyai kewajiban untuk meningkatkan kemampuan masyarakat dalam bidang IGT. IGT adalah produk turunan dari IGD dan informasi pendukung lainnya. Beberapa contoh produk IGT adalah peta batas wilayah, peta pariwisata, peta kependudukan, peta kawasan bencana, peta potensi wilayah dan lain-lain. Pemetaan partisipatif adalah salah satu metode yang cocok untuk dikembangkan dimasyarakat dalam membangun salah satu produk IGT, khususnya dalam bidang pemetaan batas wilayah administratif kelurahan. Hasil akhir dari pemetaan ini adalah peta batas wilayah kelurahan dalam satu kecamatan. Peta batas wilayah inilah sebagai salah satu informasi yang aktual bagi masyarakat dan perangkat pemerintahan yang bersangkutan dalam pengelolaan dan pengembangan wilayah yang menjadi tanggung jawabnya. Peta batas wilayah yang jelas dan telah disepakati oleh pihak-pihak yang saling bersinggungan akan meminimalkan konflik yang terjadi di masyarakat dan masyarakat dapat diberi pemahaman akan keberadaan administratif suatu lokasi/daerah secara lebih mudah dan jelas.
\end{abstract}

Kata Kunci: Peta, Batas Wilayah, Pemetaan Partisipatif

\section{PENDAHULUAN}

\section{Latar Belakang}

Undang-Undang nomor 32 tahun 2004 tentang Pemerintahan Daerah, pada pasal 1 ayat 6, menyebutkan Daerah Otonom, selanjutnya disebut daerah, adalah kesatuan masyarakat hukum yang mempunyai batas-batas wilayah yang berwenang mengatur dan mengurus urusan pemerintahan dan kepentingan masyarakat setempat menurut prakarsa sendiri berdasarkan aspirasi masyarakat dalam sistem Negara Kesatuan Republik Indonesia. Sementara Pasal 7 ayat 2 menyebutkan: "perubahan batas suatu daerah, perubahan nama daerah, pemberian nama bagian rupa bumi serta perubahan nama, atau pemindahan ibukota yang tidak mengakibatkan penghapusan suatu daerah ditetapkan dengan Peraturan Pemerintah".
Peraturan Pemerintah nomor 78 tahun 2007 tentang Tata Cara Pembentukan, Penghapusan dan Penggabungan Daerah, pasal 1 ayat 6 menyebutkan: "Daerah otonom, selanjutnya disebut daerah, adalah kesatuan masyarakat hukum yang mempunyai batas-batas wilayah, yang berwenang mengatur dan mengurus urusan pemerintahan dan kepentingan masyarakat setempat menurut prakarsa sendiri berdasarkan aspirasi masyarakat dalam sistem Negara Kesatuan Republik Indonesia".

Penentuan dan penegasan batas daerah menjadi penting karena sesuai dengan kegunaannya adalah: meminimalisir terjadinya konflik batas, sebagai rujukan kerja yang akan datang, tertib administrasi pemerintahan, perhitungan fiskal daerah, kepastian hukum dan yurisdiksi pemerintah daerah, rencana tata ruang tepat sasaran, memberi keyakinan (nilai tambah) 
kepada investor, dan implementasi good \& clean governance.

\section{METODOLOGI PENELITIAN}

\section{Lokasi Penelitian}

Lokasi kegiatan PPM ini terletak di tujuh Kelurahan yang tersebar di Kecamatan Sukolilo, Kota Surabaya, yaitu Kelurahan Gebang Putih, Kelurahan Keputih, Kelurahan Nginden Jangkungan, Kelurahan Menur Prumpungan, Kelurahan Klampis Ngasem, Kelurahan Semolowaru, dan Kelurahan Medokan Semampir

\section{Data Dan Peralatan}

- Data

Data yang digunakan dalam penelitian ini adalah:

1. Peta RBI skala $1: 25000$ lembar $1608-423$

2. Citra GeoEye tahun 2013 yang diunduh melalui Google Earth ${ }^{\mathrm{TM}}$

3. Data pendukung mengenai informasi kelurahan di Kecamatan Sukolilo.

4. Peta - peta pendukung dari kelurahan terkait.

\section{- Peralatan}

Peralatan yang digunakan dalam penelitian ini adalah Personal Computer (PC) / Notebook, Pengolah kata dan pengolah data gambar dan perangkat lunak Sistem Informasi Geografis (GIS)

\section{Pengolahan Data}

Berikut merupakan penjelasan dari diagram alir tahap pengolahan data :

1. Data Citra GeoEye

Data yang digunakan dalam penelitian ini adalah Citra GeoEye yang diunduh secara gratis melalui mozilla firefox dengan syarat sudah memasang ekstensi screengrab. Setelah proses pengunduhan data selesai, maka langkah selanjutnya adalah melakukan koreksi geometrik yang bertujuan untuk mereduksi kesalahan geometrik dengan parameter RMS eror $\mathrm{n} \leq 1$ sehingga dihasilkan citra terkoreksi secara geometrik. Setelah itu dilakukan pemotongan atau cropping citra guna mendapatkan potongan citra sesuai dengan lokasi penelitian.

2. Peta RBI lembar $1608-423$
Peta RBI lembar 1608-423 merupakan salah satu data primer yang digunakan dalam kegiatan ini.

3. Overlay Data

Seluruh data yang sudah diolah seperti data citra GeoEye yang sudah di cropping, dan peta RBI yang sudah di digitasi di overlay - kan untuk kemudian dilakukan proses penetapan garis batas.

4. Penetapan Garis Batas Wilayah dengan Metode Kartometrik dan Pemetaan Partisipatif

Penentuan batas wilayah secara kartometrik adalah penelusuran garis batas wilayah dengan menentukan posisi titik-titik koordinat dan mengidentifikasi cakupan wilayah pada peta kerja atau citra yang telah terkoreksi. Ditambahkan dengan data data pendukung seperti Peta PBB, Peta Desa dan dokumen batas yang pernah dikerjakan sebelumnya.

5. Analisa Garis Batas Alternatif

Dari hasil pengolahan data tersebut dapat dianalisa panjang segmen batas yang berbeda antara segmen batas pada peta RBI dengan segmen batas hasil diskusi bersama perangkat kelurahan .

6. Hasil dan Penyajian Data

Hasil akhir dari penelitian ini adalah Peta batas wilayah Kecamatan Sukolilo dan laporan akhir penelitian.

\section{HASIL DAN PEMBAHASAN}

Hasil dari proses pengolahan adalah sebagai berikut :

\section{Peta Dijital RBI}

Peta digital batas administrasi wilayah Kecamatan Sukolilo didapat dari hasil digitasi peta RBI di daerah tersebut. Hasil dari digitasi RBI ditampilkan pada gambar 3.

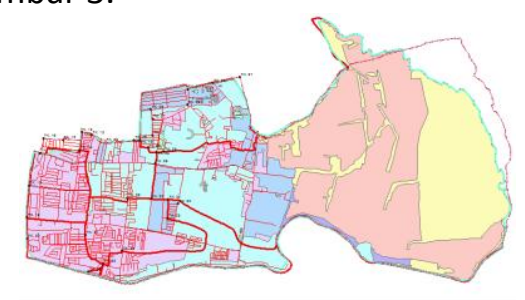

Gambar 1. Peta Digital 


\section{Citra Terkoreksi dan Cropping}

Sedangkan hasil citra GeoEye yang sudah terkoreksi dan telah dilakukan proses cropping dapat dilihat pada gambar 4 .

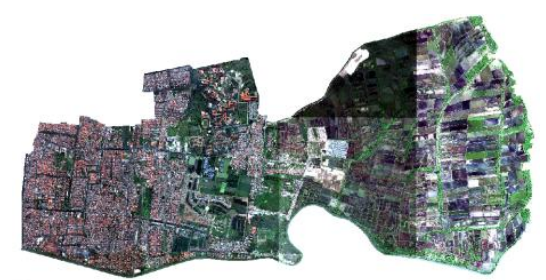

Gambar 2. Citra Terkoreksi

Setelah didapat dua data yang telah diolah yaitu data citra GeoEye yang telah terkoreksi dan peta dijital batas administrasi wilayah Kecamatan Sukolilo, ke dua data tersebut di tampalkan (overlay). Dari penampalan tersebut digunakan sebagai data penentuan batas wilayah dengan metode kartometrik (Gambar 3).

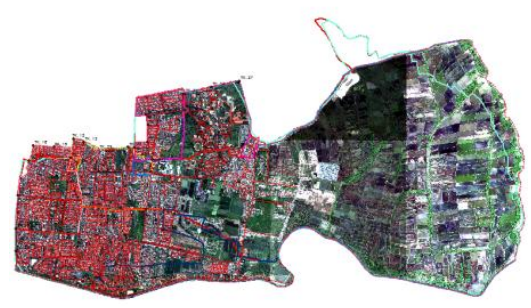

Gambar 3. Hasil Tumpang Susun Seluruh Data

\section{Peta Batas Wilayah}

Adapun kegiatan verifikasi batas Kecamatan Sukolilo ini disajikan dalam bentuk peta seperti pada gambar dibawah ini (gambar 4)

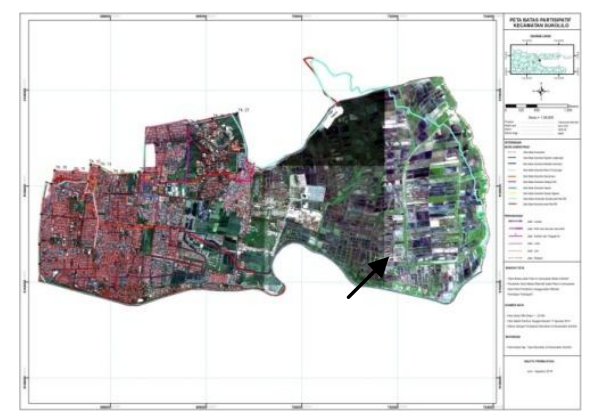

Gambar 4. Peta Batas Wilayah

\section{Titik kartometrik}

Titik kartometrik yang terdapat pada segmen batas Kelurahan di Kecamatan Sukolilo hasil kajian penelitian ini berjumlah 32 titik yang tersebar di sepanjang garis batas

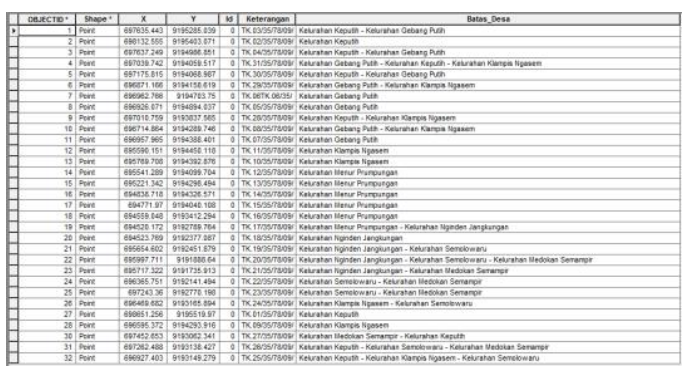

Gambar 5. Titik Kartometrik

\section{Analisa}

Dari hasil di atas, dapat dilakukan analisa sebagai berikut :

a. Analisa Perbedaan segmen batas kecamatan hasil verifikasi dengan batas administrasi pada peta RBI

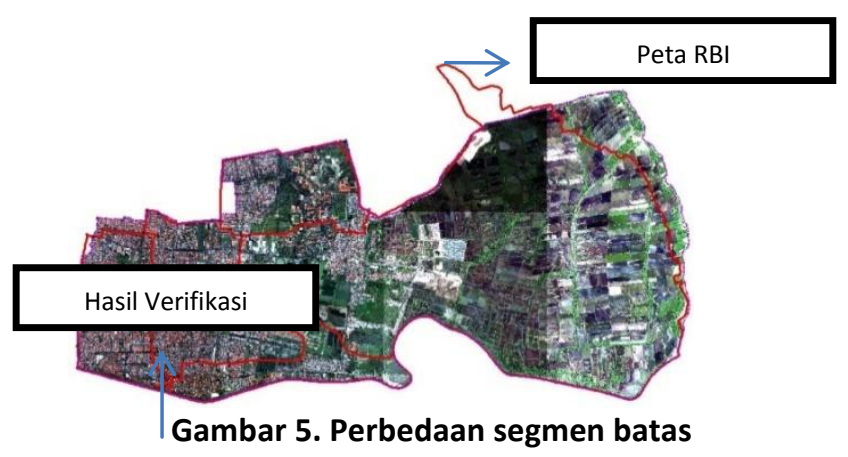

Batas wilayah yang di ambil dari peta RBI tahun 1999 pada kecamatan sukolilo ditunjukan dengan garis berwarna merah pada gambar diatas. Sementara batas hasil verifikasi ke kelurahan di kecamatan sukolilo ditujukan pada garis berwarna ungu.

b. Analisa Perbedaan segmen batas kelurahan hasil verifikasi dengan batas administrasi pada peta RBI

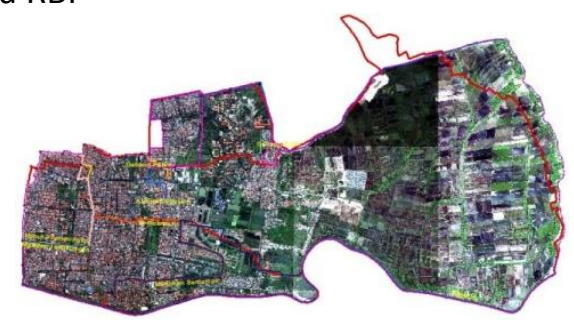

Gambar 6. Panjang Segmen Batas Kelurahan yang Berbeda

Berdasarkan perbandingan antara batas kelurahan pada peta RBI dengan batas hasil 
verifikasi terdapat jelas beberapa perbedaan segmen garis batas. Pada gambar diatas setiap garis batas hasil verifikasi perkelurahan dibuat dengan layer warna yang berbeda sementara garis batas peta RBI berwarna merah. Berikut diantaranya perbedaan garis batas di tiap kelurahan :

1. Segmen Batas Kelurahan Gebang Putih

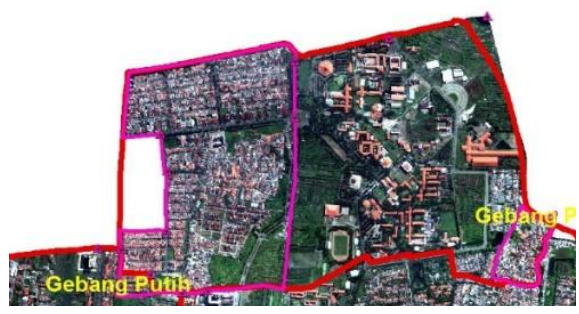

Gambar 7. Perbedaan segmen batas di Kelurahan Gebang Putih

Segmen Garis Batas Kelurahan Gebang Putih pada Peta RBI ditunjukan dengan garis berwarna merah. Sementara segmen garis batas kelurahan gebang putih hasil verifikasi adalah garis berwarna ungu.Dimana berdasarkan hasil verifikasi, kelurahan gebang putih terdiri dari dua daerah.

2. Kelurahan Keputih

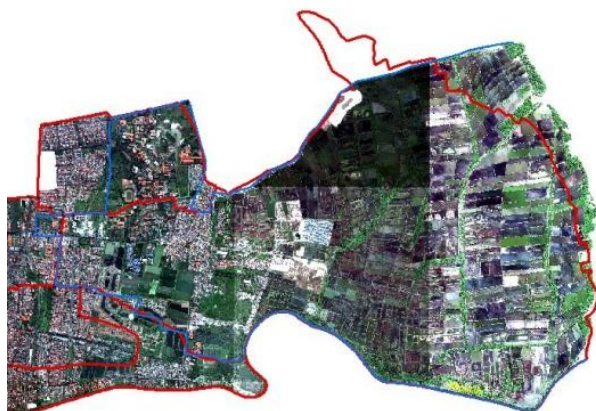

Gambar 8. Perbedaan segmen batas di Kelurahan Keputih

Segmen Garis Batas Kelurahan keputih pada Peta RBI ditunjukan dengan garis berwarna merah. Sementara segmen garis batas kelurahan keputih hasil verifikasi adalah garis berwarna biru.

\section{Kelurahan Klampis Ngasem}

Segmen Garis Batas Kelurahan Klampis Ngasem pada Peta RBI ditunjukan dengan garis berwarna merah. Sementara segmen garis batas kelurahan Klampis Ngasem hasil verifikasi adalah garis berwarna kuning.
Pada segmen garis batas ini tidak terdapat terlalu banyak perbedaan.

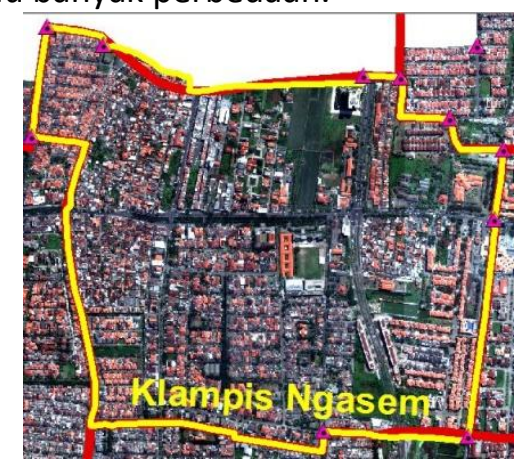

Gambar 9. Perbedaan segmen batas di Kelurahan Klampis Ngasem

4. Kelurahan Menur Prumpungan

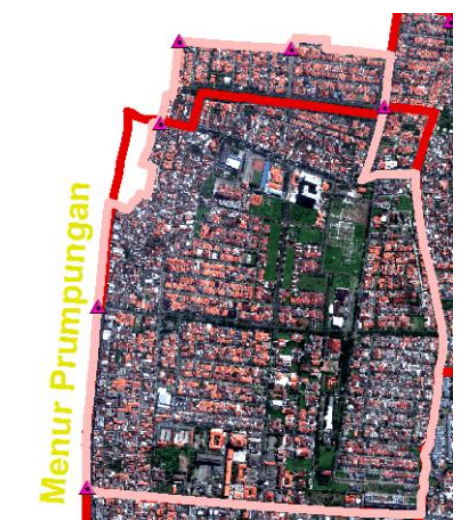

Gambar 10. Perbedaan segmen batas di Kelurahan Menur Prumpungan

Segmen Garis Batas Kelurahan Menur Prumpungan pada Peta RBI ditunjukan dengan garis berwarna merah. Sementara segmen garis batas kelurahan Menur Prumpungan hasil verifikasi adalah garis berwarna Merah muda. Pada segmen garis batas ini terdapat perbedaan yang cukup signifikan. Perbedaan batas yang terletak di Kelurahan Menur Prumpungan ini hampir di setiap segmen nya berbeda.

5. Kelurahan Nginden Jangkungan

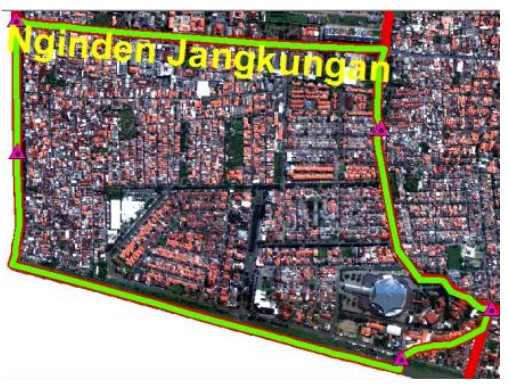

Gambar 11. Perbedaan segmen batas di Kelurahan Nginden Jangkungan 
Segmen Garis Batas Kelurahan Nginden Jangkungan pada Peta RBI ditunjukan dengan garis berwarna merah. Sementara segmen garis batas kelurahan Nginden Jangkungan hasil verifikasi adalah garis berwarna Hijau.

6. Kelurahan Semolowaru

Segmen Garis Batas Kelurahan Semolowaru pada Peta RBI ditunjukan dengan garis berwarna merah. Sementara segmen garis batas kelurahan Semolowaru hasil verifikasi adalah garis berwarna orange.

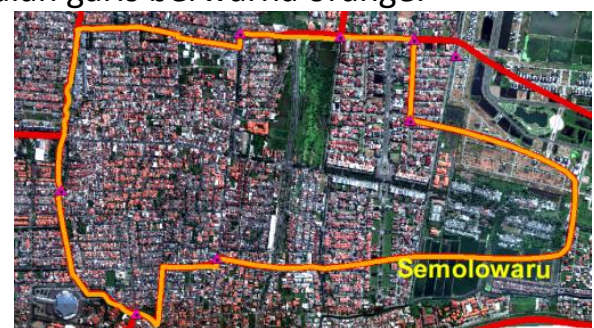

Gambar 15. Perbedaan segmen batas di Kelurahan Semolowaru

\section{Kelurahan Medokan Semampir}

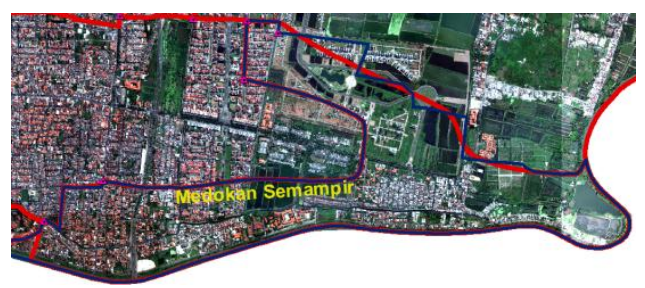

Gambar 16. Perbedaan segmen batas di Kelurahan Medokan Semampir

Segmen Garis Batas Kelurahan Medokan Semampir pada Peta RBI ditunjukan dengan garis berwarna merah. Sementara segmen garis batas kelurahan Medokan Semampir hasil verifikasi adalah garis berwarna Biru tua.

c. Proses Verifikasi

Verifikasi segmen batas di setiap kelurah di Kecamatan Sukolilo dilakukan dengan mengunjungi tiap-tiap kelurahan. Dimana peta digital yang diambil dari peta RBI di overlay dengan citra GeoEye yang kemudian dicocokan oleh aparat dari kelurahan dengan peta PBB, sketsa wilayah kelurahan dan informasi penting lainnya yang mendukung dalam penentuan batas wilayah. Adapun Kendala yang dialami dalam penentuan batas wilayah menggunakan metode kartometrik ini muncul ketika batas-batas wilayah kelurahan sulit di identifikasi pada citra dan terdapat ketidaksinkronan garis batas antar satu kelurahan dengan yang lainnya. Berikut ini beberapa batas yang masih belum jelas setelah proses verifikasi:

1. Batas Kelurahan Gebang Putih dengan Kelurahan Klampis Ngasem

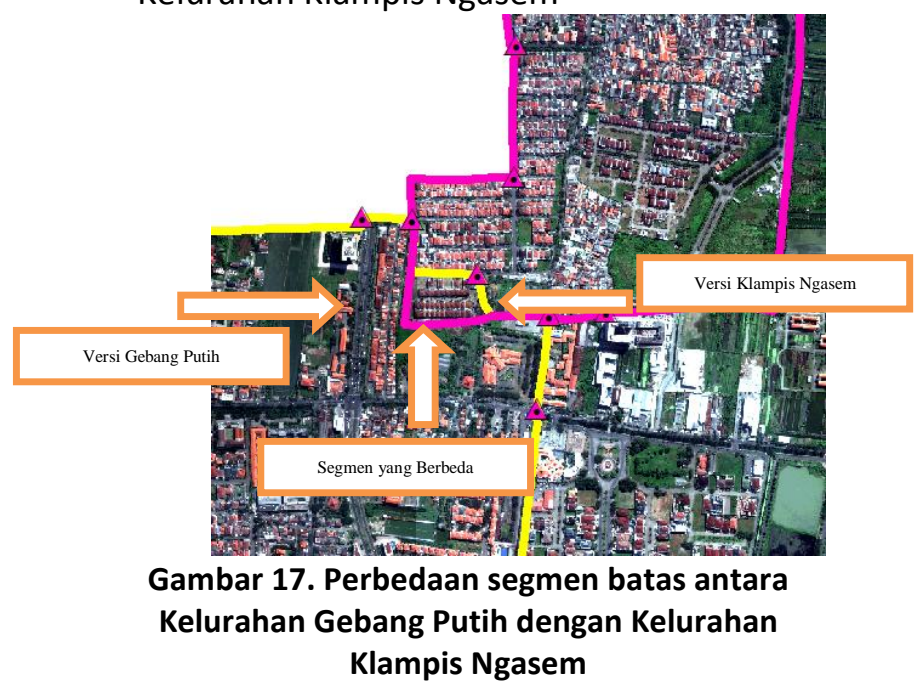

Garis batas kelurahan Gebang Putih adalah garis batas berwarna ungu. Sementara garis batas berwarna kuning merupakan garis batas Kelurahan Klampis Ngasem. Berdasarkan hasil verifikasi terdapat perbedaan garis batas antara kedua kelurahan tersebut.

2. Batas Kelurahan Keputih dan Kelurahan Klampis Ngasem.

Garis batas kelurahan Keputih adalah garis batas berwarna biru. Sementara garis batas berwarna kuning merupakan garis batas Kelurahan Klampis Ngasem.

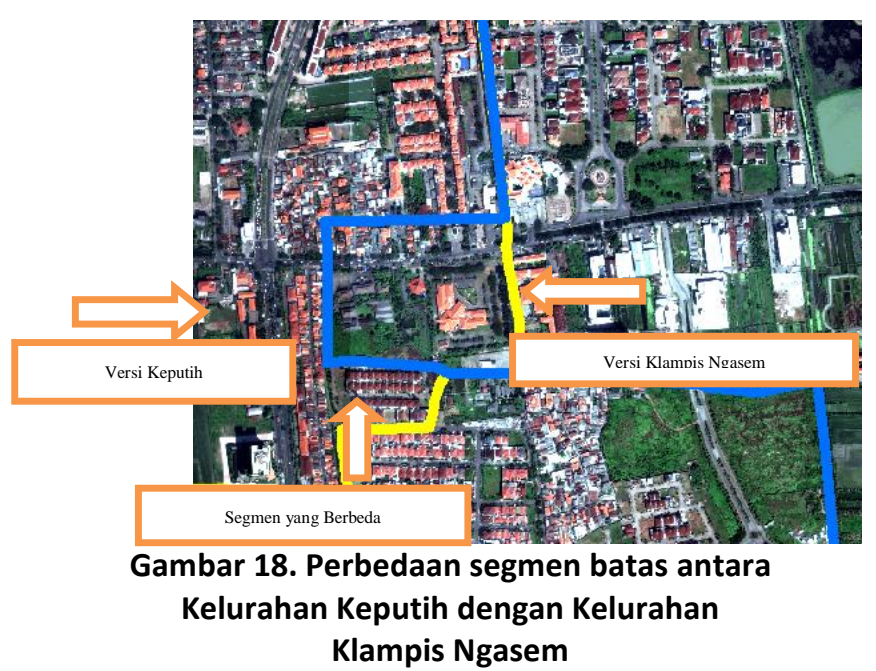


3. Batas Kelurahan Klampis Ngasem dan Kelurahan Menur Prumpungan

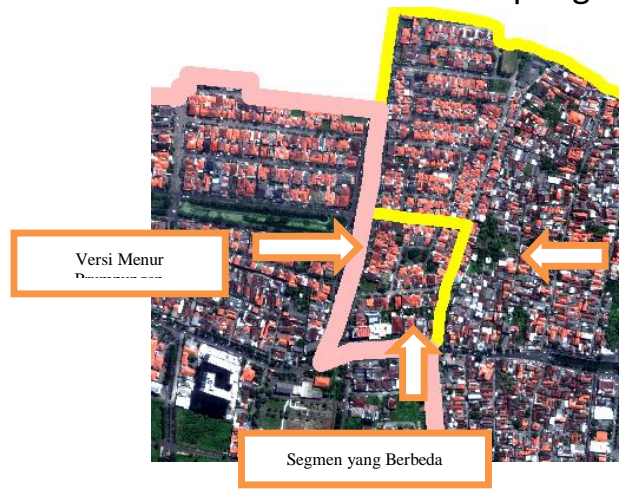

Versi Klampis Ngasen

Gambar 19. Perbedaan segmen batas antara Kelurahan Menur Prumpungan dengan Kelurahan Klampis Ngasem

Garis batas kelurahan Menur Prumpungan adalah garis batas berwarna merah muda dan berwarna kuning untuk Kelurahan Klampis Ngasem. Berdasarkan hasil verifikasi terdapat perbedaan garis batas antara kedua kelurahan tersebut. Dalam hal ini, perbedaan terjadi karena ada daerah yang tidak masuk ke kedua kelurahan yang saling berbatasan tersebut.

\section{PENUTUP}

Kesimpulan dari penelitian ini adalah :

1. Kecamatan Sukolilo terdiri dari tujuh Kelurahan, yaitu :

- Kelurahan Gebang Putih

- Kelurahan Keputih

- Kelurahan Klampis Ngasem

- Kelurahan Nginden Jangkungan

- Kelurahan Menur Prumpungan

- Kelurahan Semolowaru

- Kelurahan Medokan Semampir

2. Dari hasil verifikasi batas, terdapat perbedaan garis batas yaitu:

- Garis batas Kecamatan antara batas yang ada di peta RBI dengan batas hasil Verifikasi.

- Garis batas Kelurahan antara batas yang ada di peta RBI dengan batas hasil Verifikasi.

- Garis batas antar Kelurahan di Kecamatan Sukolilo, yaitu pada segmen batas :
- Kelurahan Gebang Putih dengan Kelurahan Klampis Ngasem

- Kelurahan Keputih dengan Kelurahan Klampis Ngasem

- Kelurahan Menur Prumpungan dengan Kelurahan Klampis Ngasem.

\section{DAFTAR PUSTAKA}

Hartanto, (2010), Pemetaan Partisipatif, http://hartanto.wordpress.com/2010/01/2 5/pemetaanpartisipatif-bersamasijampang/diakses tanggal 08-01-2014 jam 13.55

Hidayat,(2005), Seri Panduan Pemetaan Partisipatif No. 2 - Mengenalkan Pemetaan Partisipatif,Garis Pergerakan, Bandung

Negara Kesatuan Republik Indonesia. (2012a).Peraturan Menteri Dalam Negeri Republik Indonesia Nomor 76 Tahun 2012 TentangPedoman Penegasan Batas Daerah, Jakarta.

Negara Kesatuan Republik Indonesia.(2012b).Lampiran Peraturan Menteri Dalam Negeri Republik Indonesia Nomor: 76 Tahun 2012 Tentang Pedoman Penegasan Batas Daerah. Jakarta Negara Kesatuan Republik Indonesia. (2011). Undang Undang Republik Indonesia Nomor 4 Tahun 2011 tentang Informasi Geospasial.Jakarta

Negara Kesatuan Republik Indonesia. (2004). Undang Undang Republik Indonesia Nomor 32 Tahun 2004 tentang Pemerintah Daerah. Jakarta 